\title{
Taikausko ei katoa mutta sen tutkimus monipuolistuu
}

Lauri Ockenström

Magia, esoteerisuus, taikausko ja yliluonnollinen muodostavat äärimmäisen laajan, hajanaisen ja metamorfoosiherkän ilmiöjoukon. Niitä voidaan havaita kaikissa kulttuureissa kaikilla inmiselämän alueilla, ja niiden historiallinen spektri ulottuu esihistoriasta ja varhaisista korkeakulttuureista nykyhetkeen. Sateenvarjon alle mahtuu niin kirjasivistystä edellyttäviä astrologian, teosofian ja esoteeristen liikkeiden kaltaisia kulttuuriilmiöitä kuin myös kansanperinteen muotoja loitsuista ja amuleteista yliluonnollisia uskomuksia kierrättävään folkloreen ja fiktioon.

Myös ilmiöiden tutkimus on hajaantunut. Yliluonnollisia ja esoteerisia aiheita tutkitaan monilla tutkimusaloilla historiatieteistä, etnologiasta ja taidehistoriasta muun muassa kulttuurintutkimuksen eri aloihin ja psykologiaan, ja kullakin on luonnollisesti omat konventionsa ja metodinsa. Lisäksi uudenlaisia metodeihin ja teoriaan liittyviä tarpeita syntyy kaiken aikaa taikuuden ja yliluonnollisen saadessa jatkuvasti uusia representaatioita viihdekulttuurissa ja perinteiden sekoittuessa internetin eri alustoilla.

Diversiteetistä huolimatta ilmiöillä on myös yhdistäviä tekijöitä. Yksi tällainen on juuri vaikutteiden runsas siirtyminen, mukautuminen ja kyky tarrautua jatkuvasti uusiin yhteyksiin. IImiöitä yhdistää myös toinen, syvällisempi piirre: usko näkymättömiin voimiin, joita nykytiede ei selitä. Yliluonnollinen pohjavire on tehnyt aihealueesta alun alkaen haastavan tutkimuskohteen: kaikki taikauskoinen nähtiin pitkään tieteen ja oikeaoppisen uskonnon

\section{|nitillinivioilits}

irrationaalisena ja kerettiläisenä vihollisena ja siksi aiheena, joka ei sovi vakavamielisen akateemisen tutkimuksen kohteeksi.

Toisaalta sama piirre on nyttemmin tehnyt yhä relevantimmaksi tarkastella tätä laajaa ilmiöjoukkoa yhdessä - ei toki yhtenäisenä ilmiönä, vaan samankaltaisten uskomusjärjestelmien ja narratiivien osina ja osin samoja välineitä käyttäen. Viime aikoina on myös ymmärretty monitieteisen yhteistyön tarve ja eri tutkimusperinteitä yhdistävien keskustelualustojen luomisen tärkeys (tästä lisää Kentältä ja arkistosta -osiossa).

Yliluonnollisen tarkastelu myös taiteentutkimuksen näkökulmasta on tullut viime aikoina uudelleen relevantiksi. Osin tämä on seurausta viime vuosikymmenien yleisestä myllerryksestä magian ja esoteeristen alojen tutkimuksessa. Etenkin magian tutkimuksen lähtökohdat uudistettiin 1990-luvulla, minkä jälkeen tutkimusala on 
vakiintunut ja systematisoitunut. Samalla on luotu pysyvää infrastruktuuria, kuten uusia tutkimuskeskuksia ja verkostoja (esimerkiksi Center for the History of Hermetic Philosophy and Related Currents -tutkimuskeskus Amsterdamissa) ja uusia tieteellisiä julkaisuja, kuten amerikkalaisen Societas Magica -verkoston Magic, Ritual, and Witchcraft -aikakauslehti. Sama kehitys on nähtävissä myös suomalaisten esoteeristen virtausten tutkimuksessa (lisää Nina Kokkisen reportaasissa).

Toisaalta taidehistorian pitkä yhteinen menneisyys esoteerisen kanssa on asettunut uuteen valoon. Perinteisesti kuvastoja on tutkittu renessanssin ja astrologian kontekstissa tai teosofian ja mystiikan näkökulmista, kuten esimerkiksi vuonna 1998 julkaistussa Ville Lukkarisen toimittamassa Taide ja okkultismi -teoksessa. Sittemmin tutkimuskenttä on laajentunut ja fragmentoitunut samalla kun perinteisen taidehistorian rooli on pienentynyt. Viime aikoina esimerkiksi esoteeristen liikkeiden visuaalisen perinteen tutkimus on vilkastunut ja toisaalta populaarikulttuuri on synnyttänyt uusia visuaalisen kulttuurin ja yliluonnollisen kosketuspintoja.
Tämän numeron artikkelit ilmentävät monin tavoin nykykehitystä. Ne edustavat eri tutkimusaloja ja niiden kohteet ovat erilaisia, mutta tematiikassa on yhteisiä piirteitä. Esimerkiksi kontrollin tarpeen ja pelon hallinnan keinot nousevat esille useassa yhteydessä. Moderni magian tutkimus on nähnyt näissä yhden keskeisen syyn maagis-taikauskoiselle toiminnalle, mutta sen ohella ne liittävät magian osaksi laajempaa yleisinhimillistä taustaa: pohjimmiltaan sekä kauhufiktio (ja siinä tapahtuva söpöyttäminen) että taikauskoiset toimintamallit voivat toteuttaa samaa agendaa tarjoten välineitä vastata tuntemattoman pelkoon ja voimattomuuden kokemukseen.

Toinen yhdistävä teema liittyy magian ja tieteen - tai irrationaallisen ja rationaalisen - mutkikkaaseen suhteeseen. Dikotomia pohjautuu 1900-luvun alun valistushenkiseen ajatteluun jossa moderni länsimainen sivilisaatio ja etenkin tiedeyhteisö nähtiin rationalismin edustajana. Irrationalismi - ja sen tuotteet magia ja taikausko - liitettiin puolestaan menneisiin aikakausiin, vieraisiin kulttuureihin ja vaikutteille alttiisiin ihmisryhmiin kuten lapsiin ja henkisesti sairaisiin. Yhtenä tavoitteena oli päästä taikauskosta eroon osoittamalla sen loogiset virheet. Nyttemmin on tunnustettu, etteivät taikauskoiset toimintamallit katoa koulutustason noususta huolimatta, vaan ne löytävät alati uusia ilmenemismuotoja. Tosiasiassa kaikkien maailmankatsomukset, uskomukset ja arjen jokapäiväiset toimet ovat täynnä valintoja, joita voi sanoa irrationaalisiksi. Olennaista onkin voida selittää paremmin taikauskoisten taipumusten taustoja ja ymmärtää, mistä viehtymys yliluonnolliseen syntyy. Tähän liittyen itsemurhatartuntaa käsittelevä artikkeli osoittaa valaisevasti, että myös länsimaiden nykytodellisuudessa voi syntyä yleisesti hyväksyttyjä ja jopa tieteen mandaatilla toimivia selitysmalleja, joiden toimintalogiikka edustaa tosiasiassa taikauskoa.

Kolmanneksi esiin voidaan nostaa metodologinen monialaistuminen. Magian ja taikauskoisen ajattelun taustoja on ryhdytty analysoimaan aiempaa systemaattisemmin esimerkiksi kulttuurintutkimuksen eri alojen, nykypsykologian ja aivotutkimuksen menetelmin. Kuten numeron tieteelliset artikkelit ja Kentältä \& arkistosta -osion konferenssiarvio tuovat esiin, magian selittämiseksi on kehittynyt vähämielisten puuhasteluksi leimaamista selvästi parempia teoreettisia 
kehyksiä. Taikauskoisia toiminta- ja ajatusmalleja voidaan tarkastella esimerkiksi empiirisessä psykologiassa ja aivotutkimuksessa aivojen luontaisina toimintamalleina, toisaalta kulttuurintutkimuksen aloilla kulttuurin tuottamina ja ylläpitäminä rakenteina.

Uudet lähestymistavat voivat selittää melko yksinkertaisesti, miten ja miksi itsemurhatartunnan kaltainen perusteeton selitysmalli saa suosiota julkisessa keskustelussa, miksi söpöyttäminen palvelee yliluonnollisiin olentoihin kohdistuvan pelon kontrolloinnissa, ja miksi sanoilla ja symbolisilla merkeillä on uskottu olevan salaisia voimia. Tässä yhteydessähumanistista kulttuurintutkimusta, empiiristä ja kognitiivista psykologiaa ja luonnontieteitä ei tulisi nähdä kilpailevina tai poissulkevina selitysmalleina, eikä liioin ole hedelmällistä kinastella mistä muna ja kana löytyvät. On pikemminkin realistista olettaa, että inmisaivojen biologia ja kulttuurin mallit tuottavat ja pitävät molemmat yllä taikauskoista ajattelua, jota ilmenee hyvin monella eri tasolla. Taikauskoiset mallit nivoutuvat niin syvälle sekä monituhatvuotiseen kulttuuriperintöön että inmisen lajityyppiseen käytökseen, että monitieteinen yhteistyö niiden tutkimuksessa on enemmän kuin tarpeen. Tässä kehityksessä myös taiteen tutkimuksen olisi hyvä pysyä mukana.

Tämä numero koostuu kolmesta tieteellisestä artikkelista ja kahdesta arviosta. Riikka Ala-Hakula käsittelee 1900-luvun alun brittiläisen kuvataiteilijan ja okkultistin Austin Osman Sparen kehittelemää maagisten monogrammien järjestelmää. Artikkelissaan Ala-Hakula sijoittaa Sparen monogrammit osaksi maagisten symbolien pitkää historiallista kehitystä ja analysoi niiden jälkivaikutusta.

Susanne Ylönen tarkastelee zombiaiheisten kuvakirjojen tapoja esittää rumaa ja väkivaltaista kuolemaa. Artikkeli keskittyy esteettisen härmistämisen käsitteeseen, jolla tarkoitetaan pelon hallintaan tarkoitettua estetisointia tai karnevalisointia. Heidi Kosonen puolestaan käsittelee itsemurhatartunnaksi nimettyä ilmiötä. Kosonen analysoi ei-luonnollista kuolemaa käsittelevää tv-sarjaa ja vampyyri-aiheista elokuvaa ja niiden herättämiä keskusteluja tuoden esiin itsemurhatartunnan käsitteen syntyyn liittyviä prosesseja.

Kentältä \& arkistosta -osuudessa Nina Kokkinen esittelee kotimaisia esoteerisia ja teosofisia liikkeitä vuosina 1880-1940 tutkivaa monitieteistä Uuden etsijät. Esoteerisuus ja uskonnollisuuden murros -tutkimushanketta ja raportoi Turussa 29.5. pidetystä hankkeen avaussymposiumista. Hanke on merkittävä askel Suomen esoteerisen historian tutkimuksessa, ja odotamme malttamattomasti sen kontribuutiota kultakauden taiteen tutkimukseen. Omassa kirjoituksessani välitän vaikutelmia Oxfordissa meneillään olevasta Spellbound -näyttelystä ja samassa kaupungissa syyskuussa pidetystä monitieteisestä magian tutkimuksen konferenssista.

Viime aikoina tieteellisten julkaisujen vertaisarvioinnin laatutekijät ja julkaisukriteerit ovat nousseet puheenaiheeksi Helen Pluckrosen, James A. Lindsayn ja Peter Boghossianin artikkeliprovokaation myötä. Vastaava herättely olisi varmasti tarpeen monellakin tieteenalalla. Tahitissa laadusta on pyritty huolehtimaan muun muassa valitsemalla kunkin artikkelin vertaisarvioijat eri tutkimusperinteistä, ja samaa käytäntöä on noudatettu tässäkin numerossa.

Kohun myötä kotimaisessa keskustelussa nousi esiin myös eräs merkittävä taustatekijä, joka ansaitsisi enemmänkin huomiota. Tieteellisten artikkeleiden kirjoittajilta, referoijilta ja toimittajilta edellytetään korkei- 
ta laatustandardeja, suurta huolellisuutta ja virheettömyyttä, mutta useimmiten he joutuvat tekemään työnsä omalla vapaaajallaan, muun kuormituksen puristuksessa ja ilman palkkaa, eikä tämän epäkohdan korjautuminen edes siintele näköpiirissä.

Siksi haluankin lausua äärimmäisen lämpimät kiitokset tämän numeron uutterille ja huolellisille vertaisarvioijille, Tahitin päätoimittajalle ja toimitussihteerille sekä ennen kaikkea loistaville ja asiantunteville kirjoittajille. Crescant et floreant. 